\title{
Case study of safe working conditions in spanish merchant ships
}

\author{
José A. Orosa, Ph. D. \\ Universidade da Coruńa, Espańa \\ Armando C. Oliveira, Prof. \\ Universidade do Porto, Portugal
}

\begin{abstract}
Objective

This paper aims to show a practical case study of safety assessment concerning possible injuries and fire

Methods occurring in the engine room on-board a merchant ship, due to fatigue.

The methodology was centred in literature hazard identification, measurements in real ships and heat

Results stress indices definition.

Some corrections are proposed in order to obtain a safe environment for workers in the engine control room and to prevent fatigue risks at the engine room. This will allow adequate oil leakage detection and,

Discussion

as a consequence, improve fire prevention.

Training is a preventive control option, but this study allows the understanding of new corrective control options like design corrections.
\end{abstract}

Keywords: case study; safety assessment; ships, engine room

\section{INTRODUCTION}

The Spanish National Institute of Statistics reported for 2007 that the total percentage of Spanish fatal accidents at work was $1 / 3$ in the services sector, $1 / 3$ in the construction sector and

SPANISH FATAL ACCIDENTS (2007)

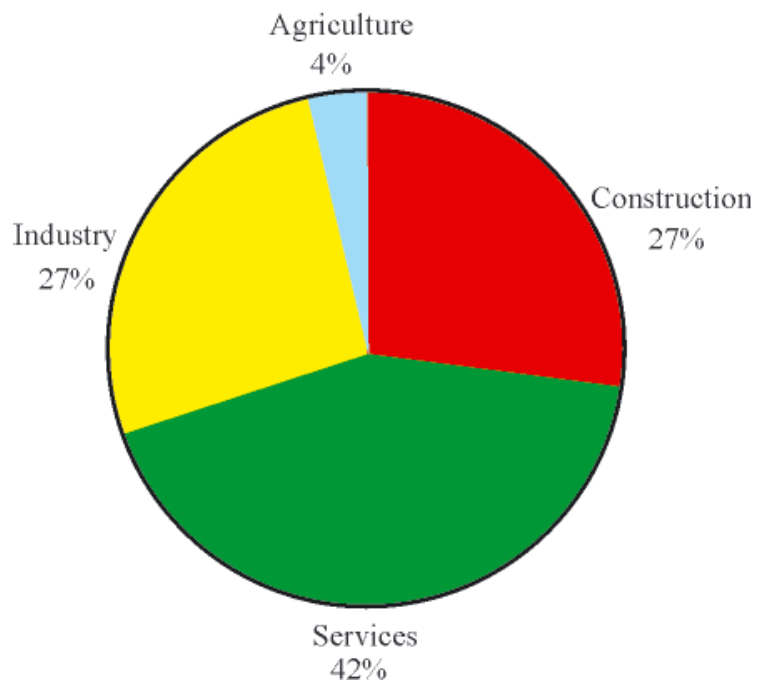

Fig. 1. Spanish total accidents in 2007 (obtained from [3]) the rest divided between the industrial and agricultural sectors, as Figs 1 and 2 show. In particular, Spanish maritime accidents have increased in the last decade from 326 accidents in 1992 to 566 in 2000 [1]. According to Fig. 3, we can conclude that commercial fishing fleets fatal accidents have been substantially

\section{SPANISH FATAL ACCIDENTS (2007)}

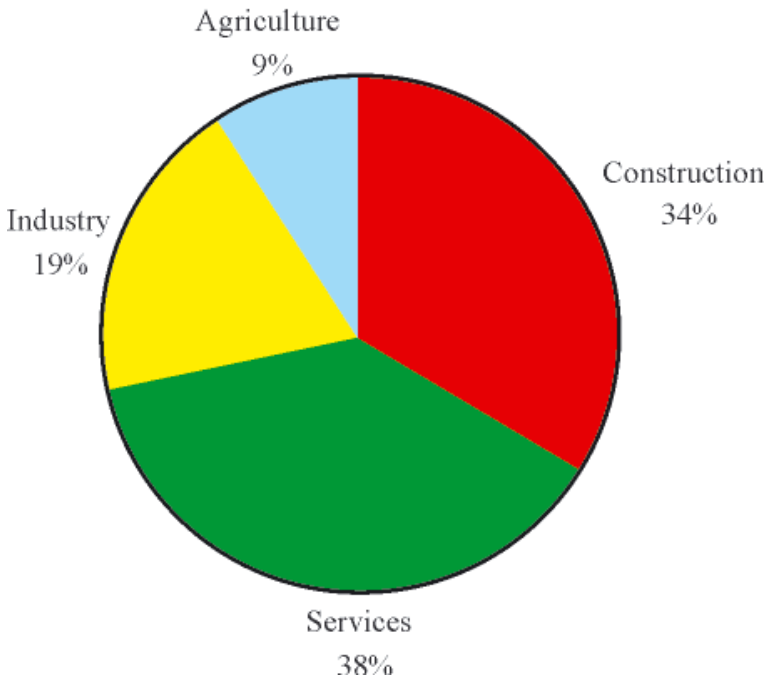

Fig. 2. Spanish fatal accidents in 2007 (obtained from [3]) 
higher than in merchant shipping $[2,3]$. Nonetheless, there are a relevant percentage of accidents taking into account the number of Spanish merchant ships [1]. Therefore, seafaring is often the second most hazardous occupation after commercial fishing in advanced western countries.

SPANISH FATAL ACCIDENTS (2007)

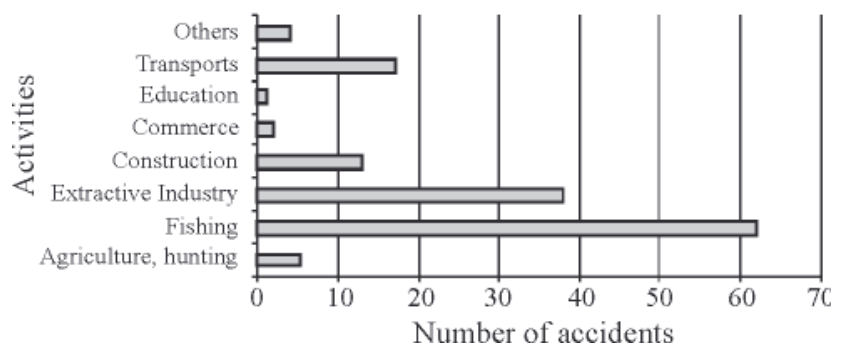

Fig. 3. Fatal accidents in Spain in 2007 year by activities - for one hundred thousands of Workers (obtained from [3])

Analyzing the total accident losses [4] in a 30-year period, Greece and Spain are the flags where the highest number of accidents caused by fire is to be found, while Japan is the lowest [4], with $20.3 \%$ and $13.4 \%$, respectively. Fire is the main hazard that we address in this paper, but we may find others such as mistakes, occupational accidents and collisions/groundings, as shown in Table 1 [5]. In particular, Table 1 shows the percentage by type of accident and Tab. 2 shows the percentage of Spanish accidents in the period from 1992 to 2000 .

Tab. 1. Percentage of Spanish flag accidents per type (obtained from [1])

\begin{tabular}{|c|c|c|c|}
\hline \multirow{2}{*}{ Accident } & \multicolumn{3}{|c|}{ Year } \\
\cline { 2 - 4 } & $\mathbf{1 9 9 2}$ & $\mathbf{1 9 9 9}$ & $\mathbf{2 0 0 0}$ \\
\hline Fire & 13.49 & 10.25 & 10.77 \\
\hline Collision & 15.33 & 10.43 & ------ \\
\hline Aground & 16.87 & 28.24 & 31.80 \\
\hline Sinking & 32.82 & 16.01 & 12.72 \\
\hline Structural Failure & 4.6 & 0.72 & 0.53 \\
\hline List & 8.58 & 12.59 & ------ \\
\hline
\end{tabular}

Tab. 2. Percentage of Spanish flag accidents in the period from 1992 to 2000 (obtained from [1])

\begin{tabular}{|c|c|c|}
\hline \multirow{2}{*}{$\begin{array}{c}\text { Type of } \\
\text { Spanish Ship }\end{array}$} & \multicolumn{2}{|c|}{ Percentage of accidents for year, \% } \\
\cline { 2 - 3 } & $\mathbf{1 9 9 2}$ & $\mathbf{2 0 0 0}$ \\
\hline Fishing & 29.5 & 28.3 \\
\hline Merchant & 55.0 & 14.3 \\
\hline Recreational & 10.4 & 57.4 \\
\hline Others & 5.0 & 0 \\
\hline
\end{tabular}

According to Det Norske Veritas (DNV) casualty statistics [4], more than $60 \%$ of all engine room fires have been initiated by hot spots. As a consequence, leaking oil hitting engine hot spots is the most common cause of engine room fire aboard ships. While the potential sources for oil leaks vary and are often difficult to stop, it is relatively easy to identify and remove hot surfaces. Then, why aren't these leaks well identified and corrected? Is it related with fatigue? This is the risk that we set out to assess and control.

To obtain an adequate work risk control, many leading societies, including Lloyds Register of Shipping and the American Bureau of Shipping, are moving towards a risk-based system. a formal ship safety assessment framework that has been proposed by the UK MCA or IMO [6], consisting of the following five steps:
1. Identification of hazards.

2. Assessment of the risks associated with those hazards.

3. Risk control options.

4. Cost-benefit assessment of the options.

5. Decision on which options to select.

\section{METHODOLOGY}

\section{Literature hazard identification}

Hazard is defined as "a physical situation with potential for human injury, damage to property, damage to the environment or a combination of the same" (MSA 1993) [7]. The best way to identify hazards is through statistical studies available in different countries [2, 8 and 9].

A general conclusion obtained in these studies was that it appears that fatalities have generally been reduced, while the rates of incidence for injuries related to vessel casualties and workplace accidents appear unchanged. The lack of apparent change in injury rates may be related to working conditions and methods, vessel design, training deficiencies and changes in the number of fishing and merchant vessels $[10,9]$.

Roberts [2] established the causes and circumstances of all traumatic work related deaths among seafarers who were employed in British merchant shipping from 1976 to 2002. The causes of death for the 564 accidents were drowning, presumed drowning, or hypothermia, injury, asphyxiation by fumes, and other causes. Accidents were classified into three categories: firstly, maritime disasters, which refer to an incident involving the ship such as collision, running aground or fire; secondly, occupational accidents occur to individual seafarers in the normal course of their work duties; and thirdly, off-duty accidents occurring to seafarers. a total of 176 deaths were caused by maritime disasters, 225 by occupational accidents and 163 by off-duty accidents.

Most of the 225 deceased had been working on deck areas at the time of the accident, and a further 29 were in the engine room. The 55 confirmed suicides were variously linked to marital and other family problems, work related problems, delirium tremens, psychiatric or physical illness, social isolation and other personal problems [2].

A further statistical study was conducted by Wang [9]. In this study, the accident data compiled by the Marine Accident Investigation Branch are presented and an analysis was carried out to determine the most common causes of accidents on fishing vessels. The investigation of these accidents has shown that in most fire events the source was originated in the engine room and was caused by oil or fuel coming into contact with hot exhaust fumes.

Analyzing the total accident losses in merchant ships, over a 30-year period, stranding is the first reason for accidents, totalling 455 cases and accounting for $30.3 \%$ of 1500 ships [4].

\section{Literature assessment of risk associated with the fire outbreak hazard}

This step aims at assessing risks and factors influencing the level of safety. Risk assessment involves studying how hazardous events or states develop and interact to cause an accident.

To determine which hazard is correlated with this risk we must apply Datasheets [11], ILO [12] and Standards [13, 14 and 15], but we must obtain real, specific information on the engine room environment, design conditions and behaviour of marine engineers to prevent work risk. This is the reason 


\begin{tabular}{|c|c|c|}
\hline Temperature & Biologic response & Heat disorders \\
\hline $20^{\circ} \mathrm{C}$ & Comfortable & Full capacity \\
\hline & $\begin{array}{l}\text { Discomfort } \\
\text { Irritability } \\
\text { Concentration difficulties } \\
\text { Decrease in intellectual capacity }\end{array}$ & Psychical disorders \\
\hline & $\begin{array}{l}\text { Increase in work mistakes } \\
\text { Decrease in handiness } \\
\text { More accidents }\end{array}$ & $\begin{array}{c}\text { Psychical and physiological } \\
\text { disorders }\end{array}$ \\
\hline$\downarrow$ & $\begin{array}{l}\text { Decrease in efficiency of heavy works } \\
\text { Disturbance of metabolism } \\
\text { Cardiac-circulatory system overload } \\
\text { Heavy fatigue }\end{array}$ & Physiological disor ders \\
\hline $35-40^{\circ} \mathrm{C}$ & Maximum bearab & erature \\
\hline
\end{tabular}

Fig. 4. Influence of environmental temperature on heat illness by Vighi [17]

why we must measure engine room variables that cause work load fatigue.

The four work load areas analysed by [5] to understand the origin of fatigue were: physical load (pushing, carrying, etc.), environmental load (temperature, noise, vibration, etc.), psychological load (tension, short cycle task, etc.) and perceptual load (reaction time, alertness, etc.).

An increased risk of general fatigue was associated with shorter tours of duty. This may reflect aspects of the work inextricably linked to tour length, such as vessel type, sector, etc. It was also associated with: fatigue when switching to port; being younger; poor sleep quality; high exposure to physical hazards; high exposure to negative environmental conditions; low job security; high job demands; high levels of stress at work; having a rank other than officer; being a smoker; and serving on a ship with a non-British flag [16].

Despite the fact that all work load areas are present in the engine room, fatigue due to heat stress is recognised as the main source of fatigue in the engine room. Measured values will allow us to understand if temperature is a real important fatigue factor, as shown in Figure 4 [17] and its effect on performance/ behaviour in the event of fire and accidents, Table 3 [5].

Tab. 3. The three level model of fatigue (obtained from [5])

\begin{tabular}{|c|c|c|}
\hline Task demands & $\begin{array}{c}\text { Health } \\
\text { consequences }\end{array}$ & $\begin{array}{c}\text { Effect on } \\
\text { performance/ } \\
\text { behaviour }\end{array}$ \\
\hline $\begin{array}{l}\text { - Physical } \\
\text { - Environmental } \\
\text { - Mental } \\
\text { - Perceptual }\end{array}$ & $\begin{array}{l}\text { - Coping capacity } \\
\text { - Health problems } \\
\text { - Life style } \\
\text { - Concentration } \\
\text { problems } \\
\text { - Fatigue }\end{array}$ & $\begin{array}{l}\text { - Mistakes } \\
\text { - Fires } \\
\text { - Occupational } \\
\text { accidents } \\
\text { - Collisions/ } \\
\text { groundings }\end{array}$ \\
\hline
\end{tabular}

In this study, we have measured air temperature and relative humidity in a Spanish merchant ship in accordance with [18]. Temperature and relative humidity data from the engine room and other locations have been analysed to obtain comfort, heat stress and fatigue indices.

\section{Literature on Preventive Control Options: Training}

The general recommendations for addressing seafarers' fatigue are summarised below $[5,16]$ :

1. Fatigue management training and information campaigns; these are likely to prove effective, but only as part of a unified approach involving all levels of authority.
2. Review how working hours are recorded; fatigue is more than long working hours, but knowing how long seafarers are working for is critical in terms of evaluating how safe current operating standards are.

3. Develop a multi-factor auditing tool; this is the combination of different risk factors that put an individual at risk of fatigue; a taxonomic or checklist-style auditing tool, therefore, needs to be developed.

Datasheet lists [19] show the different hazards to which ship-engineers and mechanics may be exposed in the course of their normal work, such as exposure to cold stress and/or heat-stress, as a result of rapid movement between cold and hot areas. The preventive measures in this case involve wearing adequate clothing and head-gear for protection in adverse weather conditions.

More specifically, ship engineers must be trained in work risk prevention $[8,20]$.

\section{Monitored variables}

Using Gemini ${ }^{\circledR}$ data loggers, air temperature, relative humidity and globe temperature were monitored on-board a merchant vessel during the Winter season. The engine room, the control room and outdoor data were measured at the same time, with one logger in each location, in order to make comparisons. More than 11,000 measurements have been collected at a frequency of 15 minutes.

To obtain measurements of working environments, dataloggers were located near the centre of gravity of workers when in their usual working position. The sampling points were located away from heat sources such as walls or air conditioning systems, in order to avoid interferences, in compliance with INNOVA recommendations [21].

\section{Indices}

To maintain thermal comfort and avoid disorders, two conditions must be fulfilled. The first is that the combination of skin and deep body core temperatures leads to a neutral feeling of comfort. The second involves the energy balance between the body and the environment. In this sense, the total metabolic heat produced by the body should be equal to the heat loss from the body.

The comfort equation developed by P. O. Fanger [22] relates physical parameters that can be measured with the neutral thermal feeling experienced by a "typical" person:

$$
\mathrm{M}-\mathrm{W}=\mathrm{H}+\mathrm{E}_{\mathrm{c}}+\mathrm{C}_{\text {res }}+\mathrm{E}_{\text {res }}
$$


where:

$\mathrm{M}$ - metabolic rate, $\mathrm{W} / \mathrm{m}^{2}$; it is the rate of chemical energy transformation from aerobic and anaerobic activities into heat and work.

$\mathrm{W}$ - rate of mechanical work performed, $\mathrm{W} / \mathrm{m}^{2}$.

$\mathrm{H}$ - heat exchange from the skin by convection, conduction and radiation, $\mathrm{W} / \mathrm{m}^{2}$.

E - evaporative heat exchange, $\mathrm{W} / \mathrm{m}^{2}$.

$\mathrm{E}_{\mathrm{c}}$ - evaporative heat exchange through the skin, in conditions of neutral thermal feeling, $\mathrm{W} / \mathrm{m}^{2}$.

$\mathrm{C}_{\text {res }}$ - respiratory heat loss by convection, $\mathrm{W} / \mathrm{m}^{2}$.

$\mathrm{E}_{\mathrm{res}}-$ respiratory heat loss by evaporation, $\mathrm{W} / \mathrm{m}^{2}$.

Through measurement of physical parameters, the above comfort equation provides an operative tool whereupon it can be assessed under what conditions thermal comfort in an occupied space is achievable. Thermal comfort can be quantified through indices defined in the ISO 7730 standard [23]. The Predicted Mean Vote (PMV) is derived from the before mentioned heat balance and provides an indication of the thermal sensation by means of a scale of 7 points, from -2 (cold sensation) to +2 (hot sensation), where 0 means a neutral thermal sensation. Another comfort index is the Predicted Percentage of Dissatisfied (PPD) that provides information on thermal sensation by predicting the percentage of people likely to feel too hot or too cold in a given environment. PMV values of -2 and +2 , mean thermal discomfort in the PPD index. Both indices are influenced by physical activity and clothing. The physical activity is quantified through the metabolic rate. The human body maintains a minimum rate of heat production of about $60 \mathrm{~W}$ during sleep. The metabolic rate is often expressed in Met, with 1 Met meaning a heat production of $58 \mathrm{~W}$ per $\mathrm{m}^{2}$ of body surface. On the other hand, clothing acts as an insulation, reducing heat loss from the body. a unit called Clo is normally used to quantify the insulation of clothes. In terms of thermal resistance, 1 Clo is equivalent to $0.155 \mathrm{~m}^{2}{ }^{\circ} \mathrm{C} / \mathrm{W}$.

The selected PMV model was developed by [22] and employed by [24] for the assessment of thermal comfort conditions in indoor environments. The expression of the model is the following:

$$
\begin{gathered}
\mathrm{PMV}=\left(0.303 \cdot \mathrm{e}^{-0.036 \cdot \mathrm{M}}\right) \cdot \\
\cdot\left[(\mathrm{M}-\mathrm{W})-\mathrm{H}-\mathrm{E}_{\mathrm{c}}-\mathrm{C}_{\mathrm{res}}-\mathrm{E}_{\mathrm{res}}\right]
\end{gathered}
$$

PPD has been also studied for the same environment. The index has been defined by the following equation, taking into account the PMV values previously obtained:

$$
\mathrm{PPD}=100-95 \cdot \mathrm{e}^{-\left(0.03353 \mathrm{PMV}^{4}+0.02179 \mathrm{PMV}^{2}\right)}
$$

As a result of the engine room conditions exceeding the range of PMV index $(-0.5$ to +0.5$)$ and the constant globe temperature during the sea-lane, we could get a specific PMV index for the engine control room.

Finally, a practical risk analysis was performed, by calculating the heat stress, Swrek indices and comparing values with standard indications. Risk control measurements can reduce the frequency of failures while mitigating their possible efforts and consequences.

According to the indications of ISO 7933 (Heat stress evaluation of severe exposures) [25] and ISO 7243 (Heat stress evaluation required sweating index) [15] standards, the graphs were obtained.

These graphs were based on human body thermal balance and show the heat that a worker must release by evaporation in a given environment to reach thermal equilibrium, expressed through:

$$
\mathrm{E}_{\mathrm{rec}}=\mathrm{M}+\mathrm{C}_{\mathrm{res}}+\mathrm{R}
$$

where:

$\mathrm{E}_{\text {rec }}-$ required evaporation to reach equilibrium, $\mathrm{W} / \mathrm{m}^{2}$.

$\mathrm{R}$ - heat gain by radiation, $\mathrm{W} / \mathrm{m}^{2}$.

As a consequence, these graphs show the maximum time that a worker should be in severe exposure, such as in engine rooms. The minimum time that the same worker must be at the control room to lose the accumulated heat was also calculated. This study is valid for a standard worker, weighing $70 \mathrm{~kg}$ and wearing light clothes.

\section{RESULTS}

\section{Analysis of monitored variables}

Because ASHRAE standards [26, 27] only discuss the different comfort zones, the European standard ISO 7730 [23] and ISO 7547 [28] have been considered in relation to the required indoor environmental conditions. Results were summarised in Table 4

Tab. 4. Statistical analysis of temperature data collected in different locations of the ship

\begin{tabular}{|c|c|c|}
\hline Temperature, $\mathbf{T}\left({ }^{\circ} \mathbf{C}\right)$ & Engine room & Control room \\
\hline Average & 32.50 & 19.76 \\
\hline Standard deviation & 2.83 & 1.33 \\
\hline Maximum & 38.50 & 27.30 \\
\hline Minimum & 25.40 & 17.40 \\
\hline
\end{tabular}

Engine room

The average temperature in the engine room was $32.5^{\circ} \mathrm{C}$ with peaks of $38.5^{\circ} \mathrm{C}$. The relative humidity was about $25 \%$, as a consequence of the high temperature.

These results exceed the values permitted for hot environments and can produce different health disorders (see Fig. 4 [5]). They may cause hyperthermia, vasodilatation and sweat gland activation, increase of peripheral circulation and electrolytic changes of sweat by loss of salt content. As fast as indoor temperature increases, the first psychical disorders appear such as loss or difficulties of concentration. Finally, physiological disorders as heart and circulatory system overload could yield.

\section{Engine control room}

As opposed to conditions in other locations, an average temperature of $19.76^{\circ} \mathrm{C}$ was recorded in the engine control room. This temperature is too low compared to the engine room, which can cause a thermal shock among workers.

Average relative humidity was $40 \%$, contrarily to the engine room, and above the minimum recommended value of $30 \%$.

\section{Outdoor conditions}

Given the influence of outdoor conditions on indoor environment, outdoor data were also registered during the monitoring period, from December to February. The results obtained were an average outdoor temperature of $23^{\circ} \mathrm{C}$, with maximum values of $27^{\circ} \mathrm{C}$, and an average relative humidity of $60 \%$. The weather was predominantly sunny and not very cloudy. 


\section{Calculated Indices}

\section{PMV and PPD}

Temperature and relative humidity values collected in the ship have been introduced in the models above described and the corresponding PMV and PPD values have been calculated for each indoor location. Once averages and standard deviations have been assessed, the values which crossed the admissible levels defined by ISO 7547 standards [6] were quantified. Such specifications set a PMV range from -0.5 to +0.5 as appropriate. This interval is equivalent to a PPD lower than $10 \%$.

In the engine control room, the PMV is close to 0.5 , which is the optimum condition for a healthy, warm environment; the average PPD is $13 \%$, and $40 \%$ of the calculated PPD data are within the $10 \%$ established in the standards. In the engine room, PMV was about 2.15 , which represents an extremely hot environment and a PPD with $77 \%$ dissatisfaction.

\section{Heat stress indices}

From the heat stress equations, the time a person should be in the control room was quantified for different globe temperatures, and showed the minimum time that a person should be in the engine room as a function of its globe temperature.

Using the graph for the engine room, we may state that the worker should have been in the engine room for 17 minutes and should have rested in the control room for at least 10 minutes, in order to allow an adequate heat release. The WBGT was about $40.2^{\circ} \mathrm{C}$, according to standards, and the SWreq time exposition limit was about 41.8 minutes. These results will be useful for training ship engineers in work risk prevention.

\section{DISCUSSION}

When analysing the obtained data, some corrections are proposed in order to obtain a healthy environment for workers in the engine control room and to prevent fatigue risks at the engine room. This will allow adequate oil leakage detection and, as a consequence, improve fire prevention. As explained, training is a preventive control option but this study allows us to understand new corrective control options like design corrections.

\section{Risk control options}

\section{Fatigue}

Measured data showed that engine room temperature is nearly independent of daily cycles. The temperature at the engine control room should be equal to $20^{\circ} \mathrm{C}$, in accordance with the air acceptability criteria, and to maintain the same PPD, the enthalpy must also be the same. For this reason, a temperature increase of $1^{\circ} \mathrm{C}$ leads to a relative humidity decrease of 5\% [29] and the above mentioned lower limit of $30 \%$ would not be fulfilled. All these facts lead to setting the existing temperature conditions as optimum for the existing relative humidity.

A possible improvement may be to increase air renovation (exchange with outdoor air) according to IS0 8861 [30], in order to cause an increase of relative humidity towards more suitable values. This increase in air renovation must ensure a positive pressure in the engine room of $50 \mathrm{~Pa}$, in accordance with ISO 8861.
Another solution is adjusting length and frequency of breaks and work periods. For this ship it was concluded that work periods inside the engine room must not be longer than twentyseven minutes and, after that, the worker must spend about ten minutes in the control room. This case study of heat stress must be taken into account when revising future standards, in order to obtain a better engine room design.

\section{Fire}

New fire detection technologies, like video cameras [16], that need less inspection time in this hot environment, must be employed. This method will allow an adequate detection of fire far away from sensors.

\section{Cost-benefit assessment of the options and decisions on which options are to be selected}

An analysis of different options showed that these options present no cost if there is an adequate design or fatigue management training. Despite the fact that corrective control options are apparently the most costly way to reduce the work risk, the initial cost can be saved with an adequate design. We must take into account that this cost will only be related to more fans to increase air renovation.

Contrarily to this, preventive methods are apparently the most economic way of solving this problem. For example, if professors provide training for marine engineers in the course of academic studies [20], the problem would be solved at the origin. As a consequence, future Spanish degrees and master studies will have to take these factors into account.

\section{CONCLUSIONS}

From this study we could identify preventive and corrective control options of fatigue risk at the engine room of a merchant ship. These conclusions will allow a more effective oil leakage detection and, in consequence, improve fire prevention.

The apparent lack of change in injury rates related to vessel casualties and workplace accidents may be related to working conditions and methods, vessel design and training deficiencies. From this analysis of real conditions, it has been possible to define a design correction involving an increase in air renovation with outdoors and preventive corrections such as limiting the time a person can work without heat stress, in accordance with ISO standards. Concerning training, more research is required to determine whether the nature and extent of training influences susceptibility to fatigue; for example, the TNO report suggested a fatigue management programme (Houtman et al., 2005 [31]). Finally, we must remember that a holistic approach to fatigue will require all layers of the industry (regulators, companies and seafarers [32]) to be involved and that there are huge potential consequences of fatigue at sea, and, likewise great benefits to be had by addressing it.

\section{BIBLIOGRAPHY}

1. Ortega J. M.: La ordenación del trabajo a bordo y su incidencia en la seguridad marítima. II Xornadas Internacionais sobre Seguridade Maritima e Medioambiente. a Coruna, Spain. 2005. http://www.udc.es/iuem/documentos/doc xornadas/ seguridademaritima/SEGURIDAD_MARITIMĀ.pdf (Accessed May 2012)

2. Roberts S. E., Marlow P. B.: Traumatic work related mortality among seafarers employed in British merchant shipping, Occup. Environ. Med. Vol. 62, 2005. 
3. Ministerio de Trabajo e Inmigración. Estadística de Accidentes de Trabajo y Enfermedades Profesionales. NIPO: 201-08-080-9. Spain, 2007. http://www.mtin.es/estadisticas/eat/eat07/index. htm. (Accessed May 2012)

4. Engine room fire. http://www.dnv.in/maritime/shipclassification/ cmc/fire_safety/engine_room_fire.asp. (Accessed May 2012)

5. Smith A., Allen P., Wadsworth E.: Seafarer fatigue: the Cardiff research programme. Centre for Occupational and Health Psychology. Cardiff University. United Kingdom. 2006.

6. MSC/Circ.1023 and MEPC/Circ.392: Guidelines for formal safety assessment (FSA) for use in the IMO rule-making process. London: IMO, 5 April 2002.

7. Marine Safety Agency. Formal safety assessment MSC 66/14. London: International Maritime Organization (Submitted by the United Kingdom to IMO Maritime Safety Committee), 1993.

8. O'Connor P.J., O'Connor N: Work-related maritime fatalities. Accident Analysis \& Prevention. Vol. 38, 2006.

9. Wang J., Pillay A., Kwon Y.S., Wall A.D.: Loughran C. G.. An analysis of fishing vessel accidents. Accident Analysis \& Prevention. Vol. 38, 2005.

10.Švetak J.: Accident investigation in the merchant marine. Pomorstvo, god. Vol. 2, 2007.

11. International Hazard Datasheets on Occupation, Ship-Engineer (Machinist). HDOEDIT (C ILO/CIS, 1999) program. Approved by DG, 1999 .

12.International Labour Organization. Accident Prevention on Board Ship at Sea and in Port. (ILO Codes of Practice), International Labour Office, Geneva, 1996. http://www.labour. gov.on.ca/english/hs/guidelines/gl_heat.html (accessed May 2012)

13.NTP 18 (Heat stress evaluation of sever exposures), http://www. insht.es/portal/site/Insht (Accessed May 2012)

14.NTP 350. Heat stress evaluation required sweating index. http:// www.insht.es/portal/site/Insht (Accessed May 2012)

15.ISO 7243. Hot environments. Estimation of the heat stress on working man, based on the WBGT-index (wet bulb globe temperature), 1989.

16.Shuenn-Jyi Wang, Dah-Lih Jeng, Meng-Tsai Tsai.: Early fire detection method in video for vessels. The Journal of Systems and Software. Vol. 82, No 4, 2009.

17.Vighi Arroyo F.: La Seguridad Industrial. Fundamentos y Aplicaciones. ETSII UPM. Ministerio de Industria y Energía, Spain. 2005. http://www.ffii.es/f2i2/publicaciones/libro_ seguridad_industrial/LSI.htm. (Accessed May 2012)

18.Wang J.: Offshore safety approach and formal safety assessment of ships. Journal of Safety Research. Vol. 33, 2002.

19. Wang J.: The current status and future aspects in formal ship safety assessment. Safety Science. Vol. 38, 2001.

20.Nas S., Paker S. D. E.: Fire Fighting Training for Officers and Captains: a Problem Based Learning Approach. International Association of Maritime Universities. 9th Annual General Assembly. 2008. http://www.iamu-edu.org/ (Accessed May 2012)

21.INNOVA Air Tech Instruments A/S. Thermal Comfort [online]. Denmark. 1997. Available from: http://www.innova.dk/books/ thermal/ (Accessed May 2012)
22.Fanger P.O.: Thermal comfort analysis and applications in environmental engineering. McGraw-Hill. USA. 1970.

23.ISO 7730. Moderate thermal environments. Determination of the $P M V$ and PPD indexes and specification of the conditions for thermal comfort. 1994.

24.Jang M.S., Koh C.D., Moon I.S.: Review of thermal comfort design based on PMV/PPD in cabins of Korean maritime patrol vessels. Build. Environ. Vol. 42, No 12007.

25.ISO 7933. Ergonomics of the thermal environment. Analytical determination and interpretation of heat stress using calculation of the predicted heat strain. 2004.

26.ASHRAE. HVAC Fundamentals. ASHRAE. Atlanta, USA, 1985.

27.ASHRAE STANDARD. Proposed Revision to an American National Standard Thermal Environmental Conditions for Human Occupancy. FIRST PUBLIC REVIEW DRAFT.2001.

28.ISO 7547 Ships and marine technology. Air-conditioning and ventilation of accommodation spaces. Design conditions and basis of calculations. 2002.

29.Simonson J.C., Salonvaara M., Ojalen T.: Improving indoor climate and comfort with wooden structures. Technical Research Centre of Finland. Espoo. VTT Building Technology, Espoo. Finland. 2001.

30.ISO 8861. Shipbuilding. Engine-room ventilation in dieselengined ships. Design requirements and basis of calculations. 1998.

31.Houtman I., Miedema M., Jettinghoff K., Starren A., Heinrich J., Gort J., Wulder J., Wubbolts S.: Fatigue in the shipping industry. TNO-report: 20834/11353. 2005.

32.Parsons K.C.: International Standards for the Assessment of the Risk of Thermal Strain on Clothed Workers in Hot Environments. The Annals of Occupational Hygiene. Vol. 43, No. 5, 1999.

\section{CONTACT WITH THE AUTHORS}

José A. Orosa, Ph. D.

Universidade da Coruńa Escuela Técnica Superior de N. y M.

Departamento de Energía y P. M.

Paseo de Ronda, 51,

15011. a Coruńa, Espańa

Corresponding author:

e-mail: jaorosa@udc.es

tel.: +34981167000 ; fax:+349811167107

Armando C. Oliveira, Prof.

Universidade do Porto, Faculdade de Engenharia,

New Energy Tec. Unit. Rua Dr Roberto Frias,

4200-465 Porto, Portugal.

e-mail: acoliv@fe.up.pt 